\title{
Coverage of energy for the preparation of hot tap water by installing solar collectors in a single- family building
}

\author{
Aleksander Starakiewicz ${ }^{1, *}$ \\ ${ }^{1}$ Rzeszow University of Technology, Department of Building Engineering, Al. Powstańców \\ Warszawy 12, 35-959 Rzeszow, Poland
}

\begin{abstract}
The paper presents the results of experimental studies on the consumption of hot water, energy obtained from the solar installation in the production process and the degree of coverage of usable and final energy with solar collectors. Thermal energy measurements from solar collectors cover the measurement period from 2011 to 2017. During this period, the annual final energy obtained from solar collectors ranged from 1033-1576 kWh. Monthly and annual demand for usable and final energy for the demand for hot water is presented depending on the amount of hot water used. Monthly actual consumption of hot water in the measurement period ranged from $3.57-9.16 \mathrm{~m}^{3}$. During this period, the number of residents has changed from 3 to 5 people. Annual coverage of energy useful for heat and energy by solar panels in the years 2011-2017 fluctuated from $38.0 \%-63.9 \%$ and $25.2 \%-42.3 \%$ for final energy. Monthly energy coverage ranged from $5.5 \%$ to over $100 \%$. Covering energy above $100 \%$ in practice means getting a higher temperature of hot water in the outlet valve than expected.
\end{abstract}

\section{Introduction}

In buildings equipped with a domestic hot water installation (DHW), it is consumed daily by users for various living needs. The amount of hot water consumed by residents depends mainly on their number, but also on the age of the people, their personal needs, habits, metering, the number of home appliances consuming hot water, equipment classes and the general desire to make savings. Every amount of hot water consumed requires a number of devices for its preparation, storage and distribution. Each of the mentioned types of devices has its own type of energy efficiency (production, storage, distribution and use) affecting the final amount of energy necessary to prepare hot water with the assumed parameters. We are therefore faced with usable thermal energy $\left(\mathrm{Q}_{\mathrm{w}, \mathrm{nd}}\right)$ for the preparation of hot tap water and the loss of energy resulting from the efficiency of the devices throughout the system. Energy for heating hot water is produced by single- or dual-function boilers, instantaneous heaters, storage heaters, compact heat centres, heat pumps, solar collectors and geothermal installations. The loss of energy (heat loss) is mainly related to the efficiency of the domestic

\footnotetext{
* Corresponding author: olekstar@prz.edu.pl
} 
hot water installation, that is its production, storage (storage tank insulation class), distribution (type of insulation of distribution and circulating pipes, circulation work time per day) and use ( $\%$ age consumption of the prepared hot water volume). Ultimately, knowledge of the usable energy and efficiency of the installation allows us to determine the final energy.

In contrast, devices that produce energy to heat hot tap water can be supplied with various fuels, such as electricity, natural or liquid gas, coal, coke, wood, fuel oil, geothermal energy, biofuel or solar. Thermal energy obtained from the said fuels is burdened with a certain production cost. Expenses borne by the residents related to the consumption of heat and power are generated by the aforementioned factors. Each user is interested in incurring the lowest possible costs, and periodically even zero. This goal can be realized for many months of the year, using a hot tap water heating installation with solar collectors. The following chapters present the actual consumption of hot tap water in a single-family house in a period of 7 years, the amount of thermal energy acquired by solar collectors as well as monthly and annual coverage of usable and final energy generated by the solar collectors.

In the single-family building in Warsaw under consideration, hot water was prepared centrally and accumulated in a bivalent tank with a capacity of 300 litres. The tank has an additional heater and two coils, where the lower one is supplied from the solar system and the upper one (if necessary) from a central heating boiler. The solar installation consists of two collectors with a total active absorber area of $4.70 \mathrm{~m}^{2}$. The collectors are directed to the south and set at an angle of $55^{\circ}$ to the level [1]. In 2013, the hot water installation was modernized by installing an additional 70-litre tank. This acts as a buffer tank performing two functions. First of all, it stores some of the hot water with a higher temperature for so-called unplanned needs (e.g. a few people bathing in a very short time) and is used to transfer high temperature water from the main tank to the buffer tank. This transfer of water increases the efficiency of solar collector installations.

\section{Consumption of hot water in a single-family building}

The consumption of hot water in a building can be estimated theoretically on the basis of various legal regulations [2-6] or measured, obtaining its actual consumption. The estimated amount of water consumed may depend on the number of users, the type of building, metering with water meters $[2,4-6]$ or relative to the area of a heated flat or building [3]. The monthly demand for hot water related to the number of residents is calculated according to the formula:

$$
G_{w}=q_{i} \cdot L_{i} \cdot L_{k} \quad\left[\frac{d m^{3}}{\text { month }}\right]
$$

where:

$\mathrm{q}_{\mathrm{i}}$ - unitary daily demand for hot water, $\mathrm{dm}^{3} /$ (person-day) $[2,4]$;

$\mathrm{L}_{\mathrm{i}}$ - number of users, people;

$\mathrm{L}_{\mathrm{k}}$ - number of days in a month, days.

The monthly demand for hot water related to the area of the heated building is calculated according to the formula:

$$
G_{w}=V_{w} \cdot A_{f} \cdot L_{k}\left[\frac{d m^{3}}{m o n t h}\right]
$$

where:

$\mathrm{V}_{\mathrm{W}}$ - unitary daily demand for hot water; $\mathrm{dm}^{3} /\left(\mathrm{m}^{2} \cdot\right.$ day $)[3]$;

$\mathrm{A}_{\mathrm{f}}$ - heated area of the building, $\mathrm{m}^{2}$.

Actual monthly and annual consumption of hot water and estimated quantities according to different legal provisions are shown in Figures $1-2,35 \mathrm{dm}^{3} /$ (person-day) for a single- 
family house according to [2], $48 \mathrm{dm}^{3} /$ (person-day) for a residential building according to [2], $120 \mathrm{dm}^{3} /$ (person -day) for a residential building according to [4] and $1.4 \mathrm{dm}^{3} /\left(\mathrm{m}^{2} \cdot\right.$ day) for a single-family building according to [3]. The heated area of the analysed building $\mathrm{A}_{\mathrm{f}}=109.89 \mathrm{~m}^{2}$.

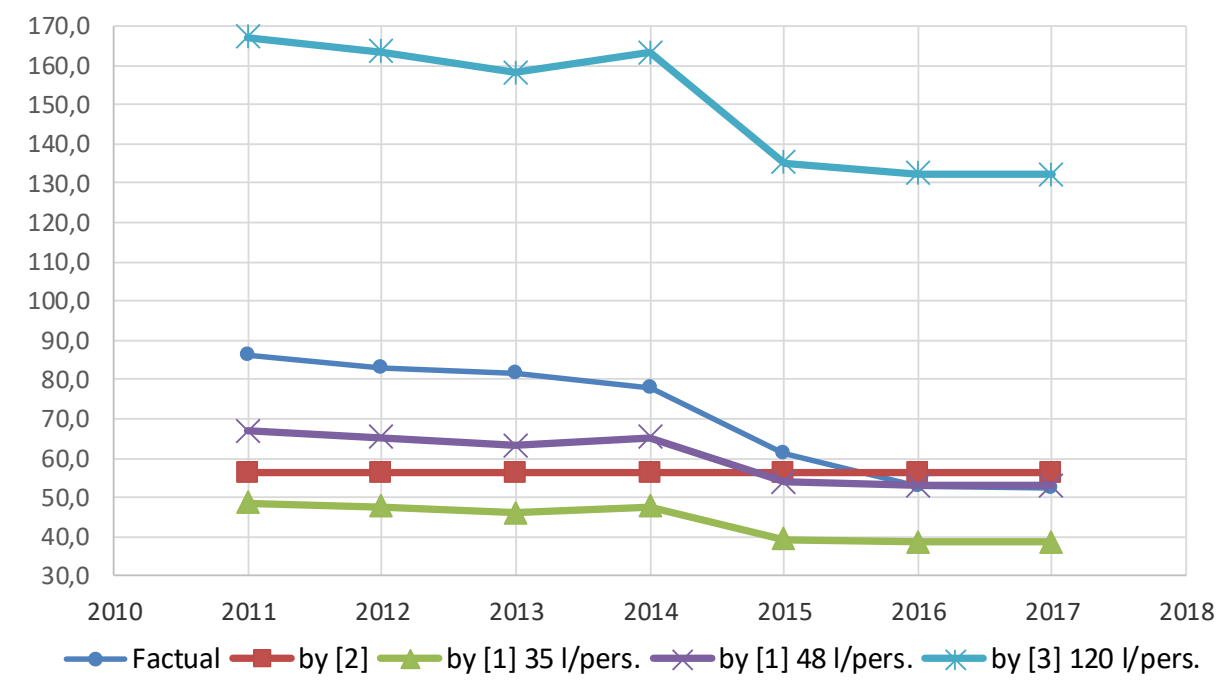

Fig. 1. Annual consumption of hot water in a single-family house in $\mathrm{m}^{3}$.

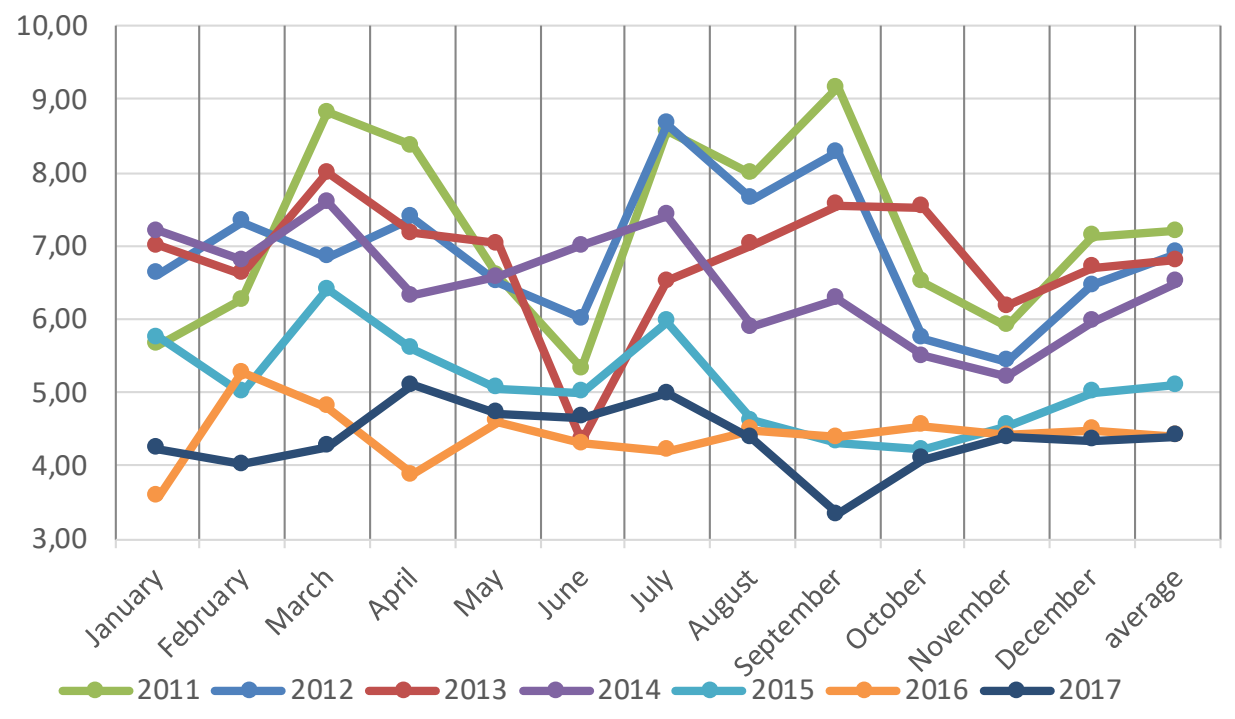

Fig. 2. Monthly and average annual consumption of hot water in $\mathrm{m}^{3}$ in the years 2011-2017.

The number of residents living in the building in the years 2011-2017 changed from 3-5 people. However, the average annual number of inhabitants in this period varied from 3.02-3.81 people. The actual number of inhabitants in particular months is shown in Fig. 3 . The fractional number of people in a given month means the proportional time of residence of a person in the building in relation to the length of a month. 


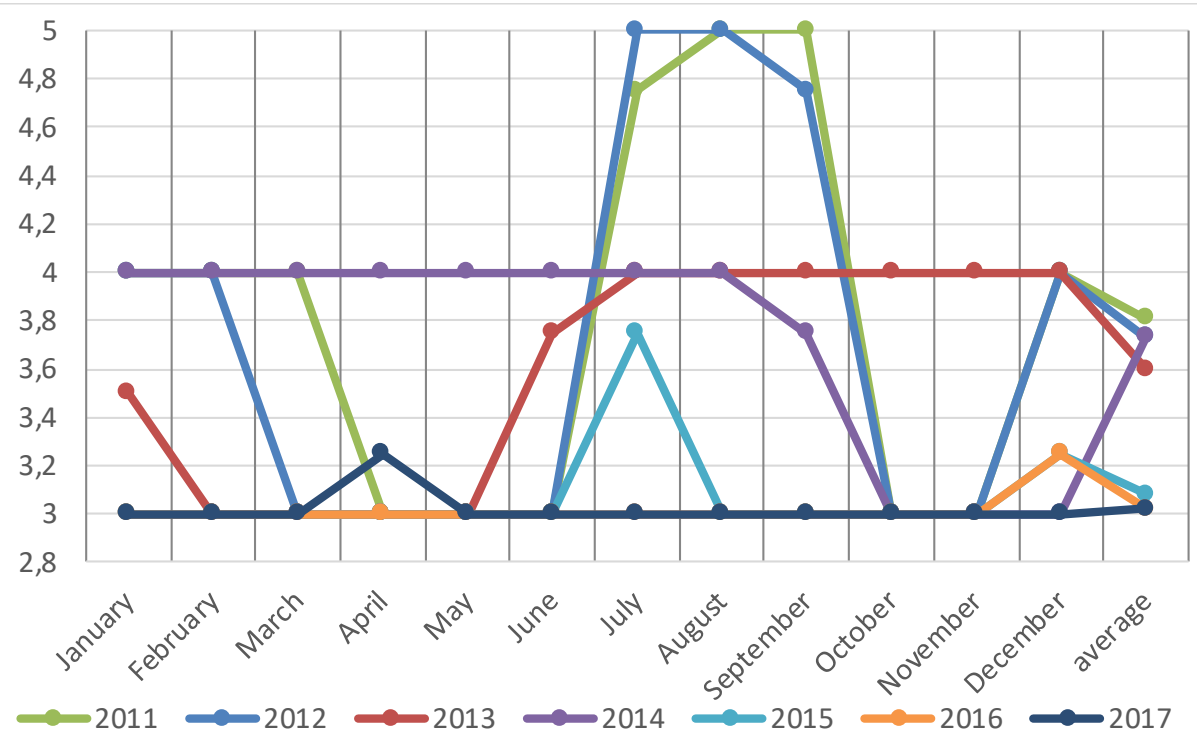

Fig. 3. Monthly and average annual number of inhabitants in 2011-2017.

\section{Demand for usable and final energy for the needs of preparing usable hot water}

Calculations of the final energy demand for the needs of hot water preparation can be performed using algorithms from the "Methodology for calculating the energy performance of a building" [3]. The final energy demand is calculated from the formula:

$$
\begin{aligned}
& Q_{K, W}=\frac{Q_{W, n d}}{\eta_{W, t o t}} \quad[k W h] \\
& \eta_{W, t o t}=\eta_{W, g} \cdot \eta_{W, d} \cdot \eta_{W, s} \cdot \eta_{W, e}
\end{aligned}
$$

where:

$\mathrm{Q}_{\mathrm{w}, \mathrm{nd}}$ - demand for useful heat for heating hot water; $\mathrm{kWh} / \mathrm{year}$;

$\eta_{\mathrm{W}, \text { tot }}$ - total annual average efficiency of the domestic hot water preparation system;

$\eta_{\mathrm{W}, \mathrm{g}}$ - average annual efficiency of heat generation from an energy carrier or energy supplied to a heat source ( 0.82 was assumed according to the data of the existing boiler);

$\eta_{\mathrm{W}, \mathrm{d}}-$ average annual efficiency of heat transfer from a heat source to hot taps $(0.95$ for the existing installation);

$\eta_{\mathrm{W}, \mathrm{s}}-$ average annual efficiency of heat accumulation in capacitive elements of the domestic hot water preparation system ( 0.85 is assumed for the existing storage tank);

$\eta_{\mathrm{W}, \mathrm{g}}$ - average annual efficiency of heat utilization (1.0 assumed).

The demand for useful heat for heating hot water is calculated as follows:

$$
Q_{W, n d}=\frac{G_{W} \cdot c_{W} \cdot \rho_{W} \cdot\left(\theta_{C W}-\theta_{Z W}\right)}{3600}\left[\frac{k W h}{\text { month }}\right]
$$

where:

$\mathrm{G}_{\mathrm{W}}$ - actual or design consumption of hot water in the building in $\mathrm{dm}^{3} / \mathrm{month}$; 
$\mathrm{c}_{\mathrm{W}}$ - specific heat of water, assumed as $4.19 \mathrm{~kJ} /(\mathrm{kg} \cdot \mathrm{K})$;

$\rho_{\mathrm{W}}$ - density of water, assumed as $1.0 \mathrm{~kg} / \mathrm{dm}^{3}$;

$\theta_{\mathrm{CW}}$ - temperature of hot water in the inlet valve (assumed as $40^{\circ} \mathrm{C}$ );

$\theta_{\mathrm{ZW}}-$ cold water temperature, based on measurements or assumed as an annual average of $10^{\circ} \mathrm{C}$.

The coverage of usable energy from the solar collector installation is calculated as follows:

$$
P_{W, n d}=\frac{Q_{K, k o l}}{Q_{W, n d}} \cdot 100 \% \quad[\%]
$$

The coverage of final energy from the solar collector installation is calculated as follows:

$$
P_{K, W}=\frac{Q_{K, k o l}}{Q_{K, W}} \cdot 100 \% \quad[\%]
$$

where:

$\mathrm{Q}_{\mathrm{K}, \mathrm{kol}}$ - final energy obtained by the solar collector installation in $\mathrm{kWh}$.

Table 1 presents the results of the study of one selected year from the period 2011-2017, i.e.: consumption of hot water in a single-family house, demand for usable and final energy, the amount of energy obtained from the solar collector installation, the amount of final energy covered by the heat source and coverage percentages of usable and final energy through the solar installation. For the calculation of usable and final energy an average daily temperature of hot water in the intake valve equal to $40^{\circ} \mathrm{C}$ was assumed.

\begin{tabular}{|c|c|c|c|c|c|c|c|c|}
\hline Month & $\begin{array}{c}\text { Consumption } \\
\text { of hot tap } \\
\text { water } \\
\mathbf{G}_{\mathrm{w}}\end{array}$ & $\begin{array}{c}\text { Temperature } \\
\text { of cold water } \\
\theta_{\mathrm{ZW}}\end{array}$ & $\begin{array}{c}\text { Usable } \\
\text { energy } \\
\text { Qw,nd }\end{array}$ & $\begin{array}{c}\text { Final } \\
\text { energy } \\
Q_{K, W}\end{array}$ & $\begin{array}{c}\text { Final } \\
\text { energy } \\
\text { from solar } \\
\text { collectors } \\
Q_{\mathrm{K}, \mathrm{kol}} \\
\end{array}$ & $\begin{array}{c}\begin{array}{c}\text { Final } \\
\text { energy } \\
\text { from heat } \\
\text { source }\end{array} \\
\end{array}$ & $\begin{array}{c}\text { Coverage } \\
\text { of } Q_{w, n d} b y \\
\text { collectors }\end{array}$ & $\begin{array}{l}\text { Coverage } \\
\text { of } Q_{\mathrm{K}, \mathrm{w}} \text { by } \\
\text { collectors }\end{array}$ \\
\hline & {$\left[\mathrm{m}^{3}\right]$} & {$\left[{ }^{\circ} \mathrm{C}\right]$} & {$[\mathrm{kWh}]$} & {$[\mathrm{kWh}]$} & {$[\mathrm{kWh}]$} & {$[\mathrm{kWh}]$} & {$[\%]$} & {$[\%]$} \\
\hline 1 & 2 & 3 & 4 & 5 & 6 & 7 & 8 & 9 \\
\hline January & 3.57 & 6 & 141.3 & 213.4 & 43.5 & 169.9 & 30.8 & 20.4 \\
\hline February & 5.27 & 7 & 202.4 & 305.7 & 64.5 & 241.2 & 31.9 & 21.1 \\
\hline March & 4.80 & 8 & 178.8 & 270.0 & 69.0 & 201.0 & 38.6 & 25.6 \\
\hline April & 3.88 & 9 & 140.0 & 211.4 & 100.5 & 110.9 & 71.8 & 47.5 \\
\hline May & 4.60 & 10 & 160.6 & 242.6 & 142.5 & 100.1 & 88.7 & 58.7 \\
\hline June & 4.30 & 13 & 135.1 & 204.1 & 162.0 & 42.1 & 119.9 & 79.4 \\
\hline July & 4.20 & 14 & 127.1 & 191.9 & 160.5 & 31.4 & 126.3 & 83.6 \\
\hline August & 4.48 & 15 & 130.4 & 196.9 & 169.5 & 27.4 & 130.0 & 86.1 \\
\hline September & 4.39 & 13 & 138.0 & 208.3 & 157.5 & 50.8 & 114.2 & 75.6 \\
\hline October & 4.54 & 10 & 158.5 & 239.4 & 40.5 & 198.9 & 25.5 & 16.9 \\
\hline November & 4.41 & 8 & 164.2 & 248.1 & 40.5 & 207.6 & 24.7 & 16.3 \\
\hline December & 4.48 & 7 & 172.1 & 259.9 & 30.0 & 229.9 & 17.4 & 11.5 \\
\hline average & 4.40 & 10 & 154.0 & 232.6 & 98.4 & 134.3 & 63.9 & 42.3 \\
\hline total & 52.92 & - & 1848.4 & 2791.6 & 1180.5 & 1611.1 & - & - \\
\hline
\end{tabular}

Table 1. Usable and final energy for the preparation of hot water and their coverage in 2016.

The cold-water temperature $\theta_{\mathrm{ZW}}$ was assumed as the average monthly value based on our own measurements. The overall efficiency of the system preparing hot tap water (capacitive storage, internal installation of the building, boiler) is $\eta_{\mathrm{w} \text {,tot }}=0.662$. This was calculated on the basis of the adopted partial efficiency [3] corresponding to the state of the installation in the analysed single-family building. 
However, Table 2 presents the average annual values of hot water consumption, the types of energy and their coverage by the solar collector installation for a period of seven years (2011-2017). Monthly coverage of usable and final energy in 2016 is shown in Fig. 4. A very high degree of coverage of usable and final energy can be observed by the solar collector installation in the four summer months (June-September) and the lowest annual coverage in the autumn months (October-December). This was a result of a very hot and sunny summer period and a cloudy autumn in 2016.

Table 2. The average annual consumption of types of energy for hot water preparation and their coverage in the period 2011-2017.

\begin{tabular}{|c|c|c|c|c|c|c|c|c|}
\hline Year & $\begin{array}{c}\text { Consumption } \\
\text { of hot tap } \\
\text { water } \\
\mathbf{G}_{\mathbf{w}}\end{array}$ & $\begin{array}{c}\text { Temperature } \\
\text { of cold water } \\
\quad \theta z w\end{array}$ & $\begin{array}{c}\text { Usable } \\
\text { energy } \\
Q_{w, n d}\end{array}$ & $\begin{array}{c}\text { Final } \\
\text { energy } \\
Q_{K, W}\end{array}$ & \begin{tabular}{|c|} 
Final \\
energy \\
from solar \\
collectors \\
$Q_{\mathrm{K}, \mathrm{kol}}$
\end{tabular} & $\begin{array}{c}\text { Final } \\
\text { energy } \\
\text { from heat } \\
\text { source }\end{array}$ & $\begin{array}{c}\text { Coverage } \\
\text { of } Q_{w, n d} \\
\text { by } \\
\text { collectors }\end{array}$ & $\begin{array}{c}\text { Coverage } \\
\text { of } Q_{K, W} \text { by } \\
\text { collectors }\end{array}$ \\
\hline & {$\left[\mathrm{m}^{3}\right]$} & {$\left[{ }^{\circ} \mathrm{C}\right]$} & {$[\mathrm{kWh}]$} & {$[\mathrm{kWh}]$} & {$[\mathrm{kWh}]$} & {$[\mathrm{kWh}]$} & {$[\%]$} & {$[\%]$} \\
\hline 1 & 2 & 3 & 4 & 5 & 6 & 7 & 8 & 9 \\
\hline 2011 & 86.3 & 10 & 2992 & 4518 & 1756 & 2762 & 59 & 39 \\
\hline 2012 & 82.9 & 10 & 2876 & 4344 & 1536 & 2808 & 53 & 35 \\
\hline 2013 & 81.6 & 10 & 2858 & 4317 & 1136 & 3181 & 40 & 26 \\
\hline 2014 & 77.8 & 10 & 2715 & 4100 & 1033 & 3067 & 38 & 25 \\
\hline 2015 & 61.4 & 10 & 2152 & 3249 & 1045 & 2204 & 49 & 32 \\
\hline 2016 & 52.9 & 10 & 1848 & 2792 & 1181 & 1611 & 64 & 42 \\
\hline 2017 & 52.4 & 10 & 1830 & 2763 & 1071 & 1692 & 59 & 39 \\
\hline $\begin{array}{c}\text { averag } \\
\text { e }\end{array}$ & 70.8 & 10 & 2467 & 3726 & 1251 & 2475 & 51 & 34 \\
\hline
\end{tabular}

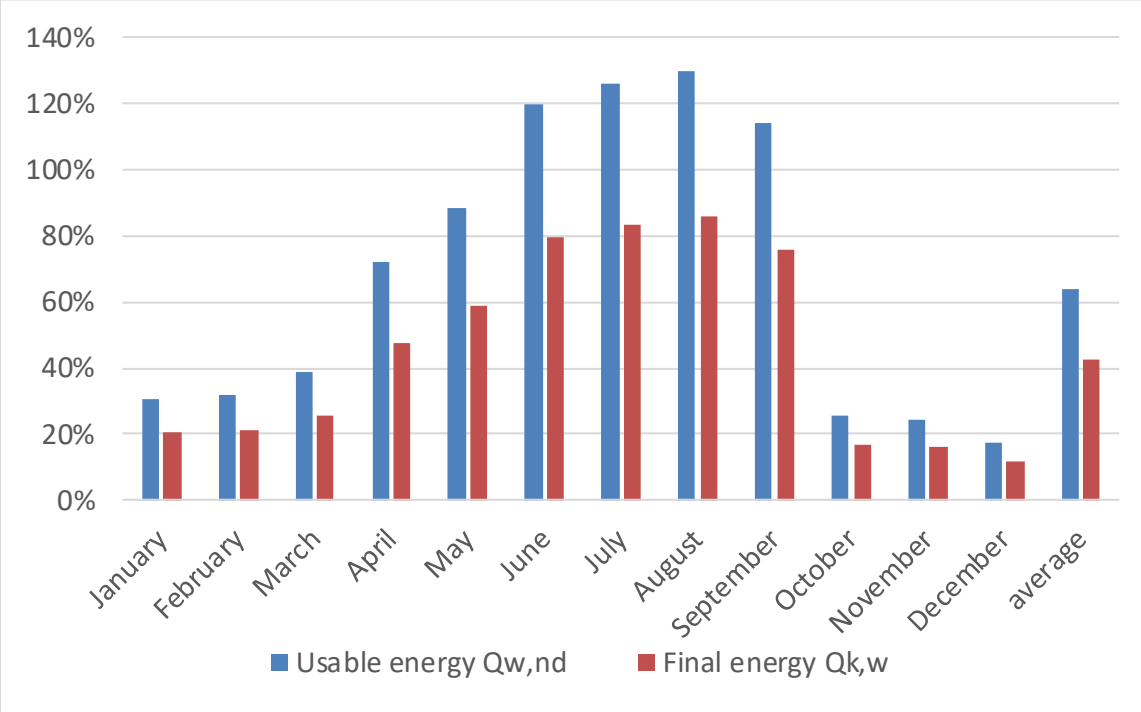

Fig. 4. Monthly energy coverage by solar collectors for the preparation of hot water in 2016. 
The average annual consumption of usable and final energy and the energy obtained from solar collectors for hot water preparation in the period 2011-2017 are shown in Fig. 5. There was a downward trend in consumption of final and usable energy in subsequent years, which is a clear effect of declining consumption of hot water in the building during this period. The decreasing consumption of hot water in the building results directly from the number of inhabitants but also from the installation of energy-saving household appliances in 2015 [7].

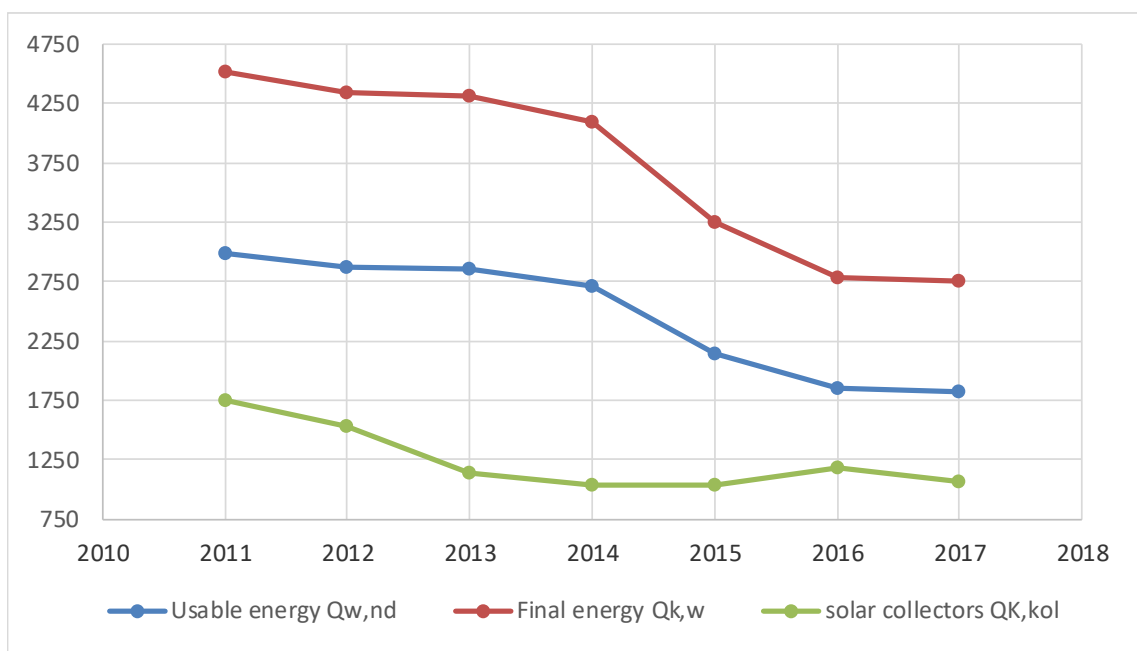

Fig. 5. Annual energy consumption in $\mathrm{kWh}$ for hot water preparation in the period 2011-2017.

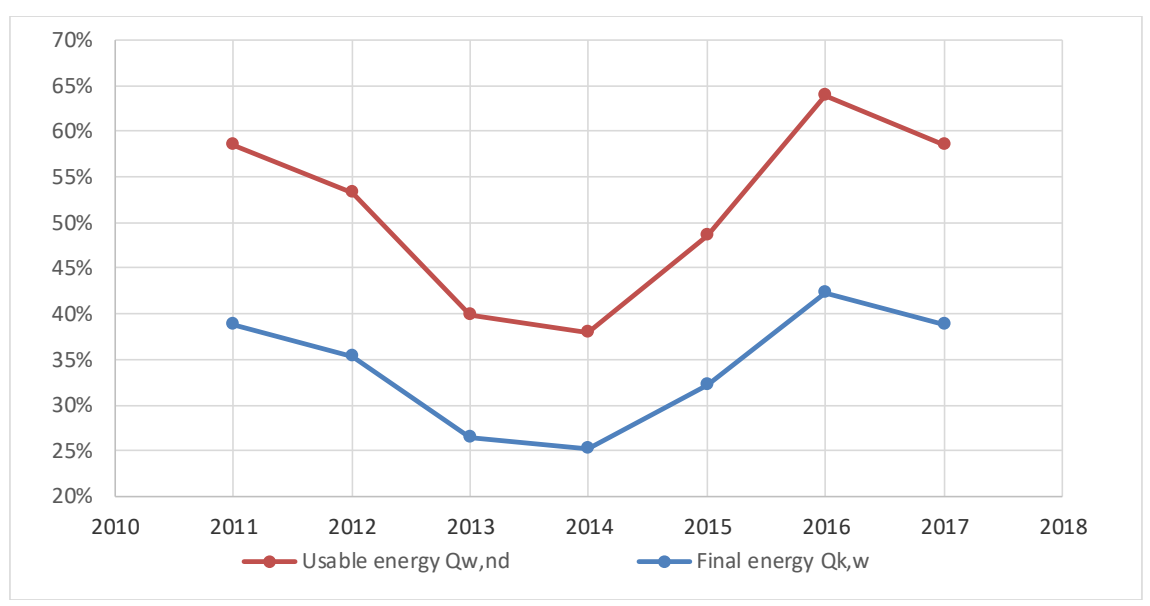

Fig. 6. Annual energy coverage for water heated by solar collectors in the period 2011-2017. 


\section{Summary}

The presented research results should be treated as a case study. They refer to one specific building, inhabited by a specific number of people and equipped with a non-standard hot water installation. Based on the results of the research, it can be concluded that the highest energy coverage for the preparation of hot water by solar collectors occurs in the summer months, i.e. from June to September. The usable energy in the summer months was covered from $37 \%-142 \%$ and the final energy from $25 \%-94 \%$ respectively. The average annual coverage of these energies in the period of 7 years was respectively: $51 \%$ of usable energy (min. 38\%, max. 64\%), final energy 34\% (min. 25\%, max. 42\%). The highest energy coverage occurred in the last two years (2016 and 2017) in which the lowest consumption of hot water per person was recorded, respectively 48.01 and $47.58\left[\mathrm{dm}^{3} /(\right.$ person-day)]. In the analysed building, the energy coverage for heating hot water depends to a large extent on the amount of its consumption. To increase the degree of energy coverage in this building, it would be necessary to increase the surface area of solar collectors or to use a different type of collectors with higher efficiency. It is true that the area of collectors related to one inhabitant $\left(1.56 \mathrm{~m}^{2} /\right.$ person $)$ is within the range of design recommendations $\left(1-2 \mathrm{~m}^{2} /\right.$ person $)$; however, this does not provide full energy coverage. Therefore, when designing solar collectors, one should also pay attention to the amount of hot water used, which will not be a simple task for most single-family houses. The operational experience shows that the building users, despite the incomplete coverage of energy needs by the solar collectors and the occasional one-day shortage of hot water, are satisfied with the benefits of this solar installation.

\section{References}

1. A. Starakiewicz, ZN PRz. 57, 509-514 (2010)

2. Rozp. Min. Infr. z dnia 6 listopada 2008 r. w sprawie metodologii obliczania charakterystyki energetycznej budynku i lokalu mieszkalnego lub części budynku stanowiącej samodzielna całość techniczno-użytkowa oraz sposobu sporządzania i wzorów świadectw ich charakterystyki energetycznej. (Dz. U. z 2008 r. Nr 201, poz.1240)

3. Rozp. Min. Infr. i Roz. z dnia 27 lutego 2015 r. w sprawie metodologii wyznaczania charakterystyki energetycznej budynku lub części budynku oraz świadectw charakterystyki energetycznej (Dz. U. z 18 marca 2015 r., poz. 376)

4. PN-92/B-01706, Instalacje wodociągowe. Wymagania w projektowaniu - wraz ze zmianą (PN-B-01706:1992/Az1:1999)

5. Rozp. Min. Spr. Wewn. i Adm. z dnia 31 maja 2000 r. zmieniające rozporządzenie w sprawie wprowadzenia obowiązku stosowania niektórych Polskich Norm. (Dz. U. z 2000 r. Nr 51, poz. 617)

6. Rozporządzenie Ministra Infrastruktury z dnia 14 stycznia 2002 r. W sprawie określenia przeciętnych norm zużycia wody. (Dz. U. Z 2002 r. Nr 8, poz. 70)

7. A. Starakiewicz, L. Lichołai, P. Miąsik, J. Krasoń, JCEEA, 63, 439-446 (2016) 